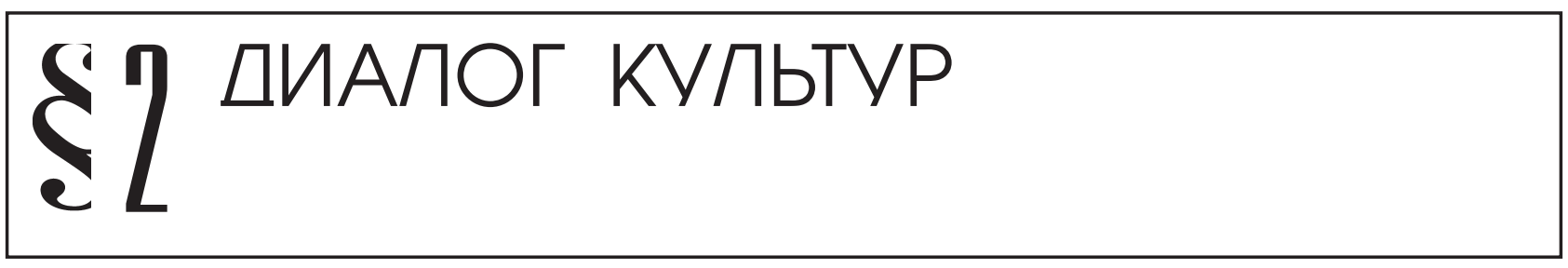

Ярцев С.В.

\title{
К ВОПРОСУ О ПОЯВЛЕНИИ ОБЩИНЫ ТАНАИТОВ НА БОСПОРЕ ВО ВТОРОЙ ПОЛОВИНЕ ІІ ВЕКА ДО НАШЕЙ ЭРЫ
}

\begin{abstract}
Аннотация: Предметом исследования является появление во второй половине II в. н.э. в составе гражданской общины боспорского города Танаиса выходиев из варварской среды - танаитов. Несмотря на популярность данной темы в исторической науке, до сих пор отсутствует единая точка зрения на этот феномен. Попытки его объяснения обычно ограничиваются прочессом седентаризации или интерпретацией танаитов в качестве вынужденных переселенцев. По мнению автора, для решения указанной проблемы необходимо обратиться к изучению общей военно-политической ситуации сложивщейся в Северном Причерноморье во второй половине II в. н.э. Таким образом, целью настоящего исследования является рассмотрение проблемы появления танаитов на Боспоре в контексте внешнеполитических устремлений Римской империи и Боспорского царства. Используя комплексный подход к источникам и конкретно сравнительноисторический метод, автор приходит к выводу, что начавшийся в середине II в. н.э. в Северном Причерноморье кризис, вызванный миграцией в регион нового массива кочевых племен, заставил римлян изменить свою стратегию в данном регионе. Империи пришлось восстановить контакты с могущественными сарматскими кланами, которые помогли утвердить римскую гегемонию и вернуть в Северном Причерноморье утраченный мир. В этом контексте, по мнению автора, и необходимо рассматривать феномен танаитов. Главный вывод исследователя заключается в том, что именно для координации военных действий с сарматскими союзниками, а также с иелью воздействия на них через культурную экспансию, отдельные представители варварской знати были организованы в равноправную с эллинами общину и расселены в Танаисе. Новая гипотеза, безусловно, будет способствовать воссозданию иелостной исторической картинь истории Северного Причерноморья римского периода.
\end{abstract}

Review: The subject under research is the appearance of Barbarian Tanaits in the civic communityof a Bosporan city Tanaits. Despite the fact that this is quite a popular theme in history, researchers still haven't come to the same point of view on this phenomenon. All attempts to explain it are usually based on the process of sedentarization or interpretation of Tanaits as forced migrants. According to the author, in order to solve the aforesaid problem, it is necessary to appeal to the overall political and military situation in the Northern Black Sea Region at the second half of the XXth century BC. Thus, the purpose of the present research is to view the origin of Tanaits on the shores of the Cimmerian Bosporus in term of foreign political aspirations of the Roman Empire and Bosporan Kingdom. In his research the author uses an integrated approach to the sources and particular comparative method and makes a conclusion that the crisis that started in mid II BC in the Northern Black Sea Region and was caused by the migration of nomadic tribes into the region forced Roman people to change their strategy in the above mentioned region. The Roman Empire had to regain their contacts with powerful Sarmatian clans who helped to strengthen the Roman hegemony and return the lost peace to the Northern Black Sea Region. It is the author's opinion $t$ we should view the phenomenon of Tanaits from this point of view. The main conclusion made by the author is that individual representatives of Barbarian noblemen were gathered to form a civic community that had the same rights as Hellenes and inhabited Tanais in order to coordinate military actions with Sarmatian allies and to influence them through cultural expansion. The new hypothesis will definitely contribute to the creation of a holistic picture of the history of the Northern Black Sea Region during the Roman period. 
Ключевые слова: Римская империя, Боспорское изарство, аланы, танаиты, тамга, стратегия, культурная экспансия, Танаис, Сарматия, позднесарматская культура.

Keywords: Roman Empire, Bosporan Kingdom, alans, tanaits, tamga, strategy, cultural expansion, Tanais, Sarmatia, late Sarmatian culture.

$\Pi$ оявление общины танаитов на Боспоре не раз рассматривалось в исторической науке, однако единой точки зрения на эту проблему нет до сих пор. Очевидно только то, что имя танаитов, безусловно, восходит к географическому термину. Во многом именно поэтому трудно интерпретировать народ с берегов Танаиса, на который и перешло указанное наименование. Изначально это могло быть любое племя, проживающее на Нижнем Дону в первых веках нашей эры. Позднее данное имя относилось к гражданской общине Танаиса - выходцам из варварской среды. В IV в., когда Танаис лежал в руинах, аланами-танаитами стали называть кочевников Нижнего Дона ${ }^{1}$.

Впервые танаиты упоминаются в надписях в качестве одного из подвластных племен Аспурга (КБН, №№ 39, 40), а также в сочинениях Плиния Старшего (Plin. NH. VI, 22) и Птолемея (Ptol. III. 5, 10). Ранее на этом основании предполагалось, что танаиты, в качестве равноправной с эллинами общины, населяли Танаис, чуть ли не с самого начала его основания ${ }^{2}$. Однако проведение дальнейших исследований заставило усомниться в этой версии. Действительно, смешанный характер некрополя с преобладанием эллинистической традиции в погребениях, противоречит предположению о присутствии варваров-танаитов в раннем Танаисе. Тем более что и Страбон упоминал сугубо эллинский состав этого боспорского города (Strabo. XI, 2,3) ${ }^{3}$. Мы разделяем точку зрения Н.В.Завойкиной и других ученых об отсутствии прямой связи между танаитами вышеназванных источников с более поздними сообщениями о го-

\footnotetext{
${ }_{1}^{1}$ Яиенко С.А. Алания I-ІІ вв. н.э. как кочевая империя // Монгольская империя и кочевой мир. Улан-Удэ, 2009. Вып. 3. С. 296, прим. 17.

${ }^{2}$ Шелов Д.Б. Танаис и Нижний Дон в III-I вв. М., 1970. С. 212-215; Шелов Д.Б. Танаис и Нижний Дон в первых веках нашей эры. М., 1972. С. 264.

${ }^{3}$ Молчанов А.А. Высшие магистраты Танаиса II-III вв. и происхождение дуалистической системы его устройства // Проблемы истории СССР. М., 1976. С. 72-74; Даньшин Д.И. Танаиты и танаисцы во ІІ-ІІІ вв. н.э. // КСИА. №197. С. 52-53.
}

родской общине танаитов ${ }^{4}$. Однако мы не можем согласиться, что танаиты представляли собой исключительно военных поселенцев находившихся на царской службе 5 .

На наш взгляд, для решения данной проблемы необходимо акцентировать внимание на военнополитической ситуации, сложившейся в Северном Причерноморье в интересующее нас время. В 40-х начале 50-х годов II в. н.э. кризис здесь достиг апогея в связи с началом миграции в регион большого кочевого массива, послужившего основой для формирования позднесарматской культуры. Несмотря на огромное пространство, которое заняла эта общность (от Южного Приуралья до Подунавья), до сих пор точно не определена территория, откуда шел на запад новый поток кочевников ${ }^{6}$. Ситуация привела к полной дестабилизации обстановки и серьезным изменениям этнической карты Северного Причерноморья. С подошедшими к Меотиде «поздними сарматами» обычно связывают жестокий разгром Танаиса в середине II в. н.э. ${ }^{7}$ Следы разрушения этого времени выявлены на всех участках древнего го-

\footnotetext{
4 Завойкина Н.В. Т $\alpha$ $\alpha \varepsilon \check{т} \alpha 1$ в истории Боспорского царства // Древности Боспора. М., 2004. С.163-197.

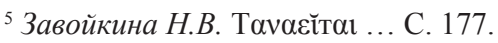

${ }^{6}$ Мошкова М.Г. Позднесарматская культура // Степи европейской части СССР в скифо-сарматское время (Археология СССР с древнейших времен до средневековья в 20 томах). М., 1989. С. 191; Мошкова М.Г. Предисловие // Статистическая обработка погребальных памятников Азиатской Сарматии. Вып. IV: Позднесарматская культура. М., 2009. С. 6-8.

${ }^{7}$ Многие авторы именно к этой группе кочевников относят появившихся в Танаисе после указанных событий танаитов (Шелов Д.Б. Некоторые вопросы этнической истории Приазовья II-III вв. н.э. по данным танаисской ономастики // ВДИ. 1974. №1. С. 92; Даньшин Д.И. Ук. соч. С. 51-56; Яиенко C.A. Аланы в Восточной Европе в середине I - середине IV вв. н.э. // ПАВ. 1993. №6. С. 84-85; Горончаровский В.А. Военно-политическая история Боспорского царства во второй половине I - середине III вв. н.э.: от прочного союза с Римом до Готских войн // МНЕМОН. Исследования и публикации по истории античного мира. СПб., 2005. Вып.4. С. 348; Безуглов С.И. Позднесарматская культура и Нижний Дон (современное состояние проблемы) // Становление и развитие позднесарматской культуры (по археологическим и естественнонаучным данным). Волгоград, 2010. С. 109).
} 


\section{Политика и общество 5 (113) • 2014}

рода. Наравне с жилыми и хозяйственными помещениями в пожаре сгорели даже башни не так давно восстановленного города ${ }^{8}$. Ольвия в это же время также была осаждена варварами и не пострадала только благодаря своевременной римской помощи Антонина Пия. При этом орда, подошедшая к Ольвии в середине II в. н.э., где она, скорее всего, соединилась с тавро-скифской группировкой с Ахиллова Бега, представляла собой довольно пестрое в этническом плане объединение 9 . Материал с могильника Бельбек IV, расположенного на территории Крыма, именно с данного времени отмечает появление тамг, имеющих аналоги не на востоке, как в предшествующий период, а в Приазовье ${ }^{10}$. Возможно, это было связано с тем, что в процессе миграции были затронуты и местные племена, кочевавшие в донских степях. Однако наибольший интерес вызывает появление вместе с мигрантами в Причерноморье особых царских составных знаков, нижняя часть которых напоминала перевернутые и сильно стилизованные трезубцы, из-за чего они и были неудачно названы В.С.Драчуком «триденсами» ${ }^{11}$. Аналоги подобным тамгам известны исключительно на западе и юге Монголии, в других регионах Евразии они полностью отсутствуют ${ }^{12}$. Таких знаков нет и на территории хоры Ольвии, что позволяет предположить, что указанные сарматские кланы не участвовали в нападении на этот город.

На пике всех этих кризисных явлений на Боспоре резко меняется власть, а вместе с ней и вся римская стратегия в Северном Причерноморье. Обычно считается, что в это время Риметалк (131/132 - 153/154) неожиданно умер и к власти пришел Ев-

\footnotetext{
${ }^{8}$ Арсеньева Т.М., Науменко С.А. Раскопки Танаиса в 19811984 гг. // КСИА. 1989. №191. С. 75-82; Арсеньева Т.М., Науменко С.А. Комплекс находок из подвала МБ ІІ-ІІІ вв. н.э. // Вестник Танаиса. Ростов-на-Дону, 1994. Вып.1. С. 61-113.

9 Если считать, что именно эту группировку римляне расселили на своей подконтрольной территории в долине рек Альма и Бельбек (Яриев С.В. Проблема этнической идентификации варваров, напавших на Ольвию во время правления Антонина Пия // ВДИ. 2011. №2. С. 144-164).

${ }_{10}$ Яцеенко С.А. Знаки-тамги ираноязычных народов древности и раннего средневековья. М., 2001. С. 41.

${ }^{11}$ Боковые отроги «триденса» невозможно свести к простому искажению настоящего трезубца, тем более, что последних на изображениях никогда не опускали вниз (Яценко С.A. Знаки-тамги ... С. 50).

12 Яиеекко С.А. Знаки-тамги ... С. 50-51.
}

патор $(154 / 155-170 / 171)^{13}$. Однако нам ничего не известно о родственных отношениях этих царей ${ }^{14}$ и обстоятельствах смены власти в середине II в. н.э. То, что вместе с Тиберием Евпатором на Боспор вновь вернулись царские тамги иранской правящей династии, идущей от Асандра, Динамии и Аспур$\mathrm{ra}^{15}$, безусловно, подтверждает серьезные перемены в отношениях между античным миром и сарматскими племенами. Так, археологические источники свидетельствуют, что после середины II в. н.э. резко увеличивается приток сарматов на территорию Крымской Скифии ${ }^{16}$, где соответственно становится больше сарматских тамг ${ }^{17}$. Не исключено также, что именно Евпатор, по указанию Антонина Пия ${ }^{18}$, в самый кризисный момент осады Ольвии с опорой на родственные сарматские кланы, взял штурмом столицу тавро-скифов. Видимо, этим он помог римлянам разрешить сложную ситуацию, а себе утвердиться на боспорском троне ${ }^{19}$. После захвата Неапо-

13 Фролова Н.А. Из истории Боспора в середине II в. н.э. // ВДИ. 1972. №1. С. 191.

${ }^{14}$ Гайдукевич В.Ф. Боспорское царство. М; Л., 1949. С. 486.

${ }^{15}$ О.В.Шаров, вслед за Д.Б.Шеловым (Шелов Д.Б. Тамга Риметалка // Культура античного мира. М., 1966. С. 273) допускает, что смена генеалогической линии на Боспоре, могла произойти еще начиная с Риметалка (Шаров О.В. Боспор и варварский мир Центральной и Восточной Европы в позднеримскую эпоху (середина II - середина IV вв. н.э.). Автореф. дис. ... док. ист. наук. СПб., 2009. С. 18-19). Однако отметим, что тамга этого царя выделена только предположительно (Яценко С.А. Знаки-тамги ... С. 51-52).

${ }^{16}$ Храпунов И.Н. Этническая история Крыма в раннем железном веке // Боспорские исследования. Симферополь; Керчь, 2004. Вып.VI. С. 118-119.

17 Пуздровский А.Е. Политическая история Крымской Скифии (ІІ в. до н.э. - IІІ в.н.э.) // ВДИ. 2001. №3. С.112.

${ }^{18}$ Пуздровский А.Е. Ук. соч. С. 110-111.

${ }^{19}$ В этой связи сильно смущает золотой статер Риметалка 150/151 гг. найденный на территории Неаполя, и являющийся, по мнению, Ю.П.Зайцева платой боспорскому воину за участие в войне против скифов (Зайщев Ю.П. Золотой статер Риметалка из Неаполя Скифского // СА. 1990. №1. С. 259261). Если предположить, что на Неаполь ходил походом все же Риметалк, тогда возможно именно он спровоцировал ответное нападение тавро-скифов на Ольвию. Евпатор в этой ситуации был вынужден осуществить полномасштабное вторжение родственных сарматских кланов на территорию Крымской Скифии. Экспансия этого царя в направлении Предгорного Крыма подтверждается рядом артефактов. Так, по мнению А.Е.Пуздровского, беспаспортная бронзовая пряжка с тамгой Евпатора, хранящаяся в Крымском 
ля Скифского большие площади города пришли в запустение, перестали функционировать городские ворота, а в помещении с дорогостоящими фресками сарматами были нанесены многочисленные тамги. Анализ этих знаков показывает, что некоторые из них в своей нижней части состояли из дуговидного отростка, напоминающего половину тамги Фарзоя (без зеркального отображения?), другие были похожи на тамгу Инисмея. Было также замечено сходство многих знаков с тамгами, встречающимися на памятниках не только Боспора, но и Ольвии ${ }^{20}$. Все это не противоречит нашему предположению, что именно Евпатор имел отношение к взятию Неаполя.

При этом очевидно, что заключение договора с сарматами удалось достичь благодаря родственным связям нового боспорского царя. Это подтверждает анализ тамги Тиберия Евпатора, верхняя часть которой имела отношение к клану родственному царице Динамии, а нижняя изображала упомянутый нами выше позднесарматский «триденс» ${ }^{21}$. Появление таких знаков обычно связывают с процессом сливания тамг двух разных кланов в ходе заключения династических браков ${ }^{22}$ (в нашем случае, родственной между собой боспорской и среднесарматской знати и представителей позднесарматской культуры $)^{23}$, хотя, на примере тех же германцев, сарматские тамги могли получить распространение и по причине установ-

республиканском краеведческом музее (Соломоник Э.И. Сарматские знаки Северного Причерноморья. Киев, 1959, С. 133-135, № 79), могла происходить с территории Неаполя Скифского, бронзовая же фибула с этим же знаком была обнаружена в Гурзуфе (Соломоник Э.И. Ук. соч. С. 130, №68; Пуздровский А.Е. Ук. соч. С. 110-111).

20 Дашевская О.Д. Граффити на стенах здания в Неаполе Скифском // СА. 1962. №1. С. 259-261.

${ }^{21}$ Яиченко С.А. Знаки-тамги ... С. 52.

22 Яиеенко С.А. Знаки-тамги ... С. 20.

${ }^{23}$ Видимо, в этом кроется причина трудности определения происхождения переселившихся в Танаис танаитов. Если одни ученые, как уже говорилось выше, считают их выходцами из позднесарматской среды, то другие говорят о среднесарматском происхождении переселенцев (Яценко С.A. К дискуссии об оформлении позднесарматской этнокультурной общности 2-й пол. II - 1-й пол. III вв. н.э. // Нижневолжский археологический вестник. Волгоград, 2011. Вып. 12. С. 197-213; Батиева Е.Ф. Население Нижнего Дона в IX в. до н.э. - IV в. н.э. (палеоантропологическое исследование). Ростов-на-Дону, 2011. С. 81). ления союзных отношений ${ }^{24}$. Поэтому Евпатору, Савромату II, Рескупориду II не было необходимости брать в жены только принцесс из сарматских племен ${ }^{25}$ - достаточно было заключить договор с могущественным сарматским кланом, ведь через некоторых общих предков боспорская и сарматская знать и так уже являлись родственниками. Двухсоставные тамги боспорских царей второй половины II - начала III вв. н.э., по-видимому, как раз и отражают данный союз. Делая вывод по поводу значения данных тамг, С.Ю.Сапрыкин совершенно верно заметил, что в качестве царских знаков они необходимы были для того, чтобы варварские вожди или царьки воспринимали своих боспорских суверенов как своих владык, а не как просто союзников ${ }^{26}$.

Но если исходить из такой интерпретации, то именно римская сторона должна была сыграть ключевую роль в урегулировании отношений с сарматами. На это указывает применение к кочевникам традиционного римского принципа воздействия на варваров через культурную экспансию ${ }^{27}$. Дело в том, что буферная территория в представлении римлян всегда являлась ареной борьбы не только в сфере войны или политики, но и культуры. Распространение римских ценностей в кругу высшей варварской знати являлось одной из главнейших задачей римской стратегии, ведь ослабление эллино-римского начала неизбежно усиливало варварское (Arr. Per. 1) и грозило превращением эллинов в варваров. В качестве примера такой трансформации можно привести историю деградировавших причерноморских ахейцев (Amm. Marc. XXII. 8,25) 28 . Поэтому пойти на договор с сарматскими кланами римская администрация и боспорские власти могли лишь на условии интеграции варварской знати в греко-римскую среду. По-видимому, этим и объяс-

\footnotetext{
24 Яиеенко С.А. Знаки-тамги ... С. 22.

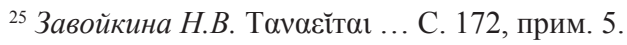

${ }^{26}$ Сапрыкин С.Ю. К вопросу о сарматизации Боспора рубежа нашей эры // Северное Причерноморье в эпоху античности и средневековья. Труды ГИМ. М., 2006. Вып. 159. С. 242.

${ }^{27}$ Перевалов С.М. Римская стратегия на Кавказе в Каппадокийское легатство Флавия Арриана // Перевалов С.М. Тактические трактаты Флавия Арриана: Тактическое искусство; Диспозиция против аланов (Сер. Древнейшие источники по истории Восточной Европы). М., 2010. С. 326.
}

${ }^{28}$ Перевалов С.М. Римская стратегия ... С. 329. 


\section{Политика и общество 5 (113) • 2014}

няется расселение Евпатором представителей союзных родственных варварских кланов, организованных в самостоятельную и равноправную с эллинами общину во главе с архонтами, в восстановленном Танаисе. Отчасти это напоминало практику некоторых греческих городов эллинистического Востока, где местное население также нередко объединялось в политевму (самоуправляющуюся общину). Варварская община продолжала называться традиционным именем - танаиты (КБН №oo 1237, 1242 , 1245, 1251a, 1251), то есть так же, как звали их предков раньше, когда они кочевали в донских степях и являлись опорой своего ставленника на боспорском престоле - Аспурга (КБН. №№ 39, 40) ${ }^{29}$. Судя по именам, получившим распространение в городе после середины II в. н.э., община танаитов была этнически неоднородна ${ }^{30}$. Помимо иранских ${ }^{31}$, В.П.Яйленко в ономастике Танаиса выделяет еще 17 имен, имеющих явно гуннское происхождение ${ }^{32}$.

${ }^{29}$ Шелов Д.Б. Танаис и Нижний Дон в III ... М., 1970. С. 212215; Шелов Д.Б. Танаис и Нижний Дон в первые века ... М., 1972. С. 264; Завойкина Н.В. Таvфєйта1 ... С. 163-197; Завойкина Н.В. Боспорские фиасы: между полисом и монархией. М., 2013. С. 180-209. А.И.Иванчик восстанавливая в надписях фиасотов из Танаиса должность эллинарха, которая действительно немыслима без существования двух общин - эллинов и танаитов, предлагает допустить существование последних еще в эллинистическую эпоху (Иванчик А.И. Три надписи фиасов эллинистического времени из Танаиса (новые данные о греко-иранском взаимодействии в Танаисе дополемоновской эпохи) // ВДИ. 2008. №2. С. 57-67). Однако это вызвало справедливые возражения В.П.Яйленко и Н.В.Завойкиной, обративших внимание на недостаточность палеографического обоснования автора и наличие противоречий с законами социальной эволюции данных микрогрупп, ведь формуляр посвятительных надписей не мог не меняться в течение двух - трех столетий - это в принципе невозможно. Палеография и сложная иерархия указанных сообществ, позволяет отнести указанные памятники ко времени не ранее II в. н.э. (Яйленко В.П. Тысячелетний боспорский рейх. История и эпиграфика Боспора VI в. до н.э. - V в. н.э. М., 2010. С. 598-599; Завойкина Н.В. Боспорские фиасы ... C. 98-101).

${ }^{30}$ Внуков С.Ю. Время и политические последствия появления племен позднесарматской культуры в Причерноморье // ВДИ. 2007. №4. С. 168.

${ }^{31}$ Шелов Д.Б. Некоторые вопросы этнической истории ... C. 83-85.

32 Яйленко В.П. Гунно-болгары II-V вв. н.э. на Боспоре по данным эпиграфики и антропонимики // Древности Боспоpa. М., 2002. Вып. 5. С. 317-320; Завойкина Н.В. Таvавйта ... C. 166 .
Несомненно, размещение в Танаисе двух равноправных общин эллинов и танаитов должно было усилить обороноспособность города ${ }^{33}$. Это хорошо согласуется с наблюдениями Г.А.Цветаевой, обратившей внимание, что в планировке Танаиса со II в. н.э. явно прослеживается влияние римских крепостей, а помещения около оборонительной стены имеют сходство с римскими казармами. Предположение ученого о дислокации здесь воинского гарнизона тем более ценно, если учитывать выявленную сеть укрепленных городищ - форпостов, возведенных на правом высоком берегу Дона и Мертвого Донца, возможно, являющихся своеобразным Танаисским лимесом ${ }^{34}$. Однако в этой связи необходимо заметить, что высокий статус и особое положение танаитов во главе с архонтами и военными предводителями-лохагами явно не соответствует малочисленности их общины. Тем более невозможно считать последних бывшими кочевниками, укрывшимися за боспорскими стенами от «поздних» сармат $^{35}$, ведь тогда трудно будет объяснить, каким образом позднесарматский «триденс» был воспринят этими предположительными беженцами. На самом деле, очевидно, что за предоставление определенных льгот, в первую очередь экономических, варварская знать, включенная в состав полисной структуры античного города в качестве полноправных граждан, должна была обеспечить безопасность вверенного ей города ${ }^{36}$. Достичь этого танаиты могли, только контролируя сарматские орды, выходца-

\footnotetext{
${ }^{33}$ Завойкина Н.В. Таvаєйта1 ... С. 177.

${ }^{34}$ Цветаева Г.А. Боспор и Рим. М., 1979. С. 45-48.

35 Яиенко С.А. К дискуссии ... С. 197-213.
}

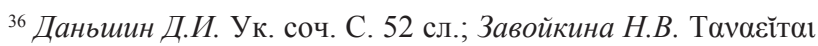
... С. 168. Сомнительно, чтобы танаиты могли нести трудовую повинность по примеру римских легионеров расквар-

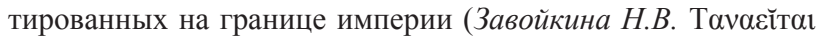
... С. 177). Участие в строительных работах для всех этих варваров, скорее всего, не выходило за рамки финансирования богатыми сарматскими кланами возведения и ремонта, в первую очередь, оборонительных сооружений города. Традиционные же занятия скотоводством, торговлей и, возможно, ремеслом, безусловно, являлись вторичными по отношению к основной военной функции переселенцев (Вдовченков E.B. Сарматизация Танаиса как частный случай взаимодействия цивилизации и варварства // Цивилизация и варварство: трансформация понятий и региональный опыт. М., 2012. С. 197-219; Вдовченков Е.В. Сарматы в Танаисе: культурные последствия седентаризации // Боспорские чтения. Керчь, 2013. Вып. XIV. C. 81-85). 
ми из которых они, скорее всего, и являлись. Это хорошо просматривается по археологическому материалу Танаиса после середины II в. н.э. (появление курганного могильника с сарматскими чертами возле города, искусственной деформации черепов у погребенных в некрополе Танаиса и т.д.) $)^{37}$. Скорее всего, орды, имеющие отношение к танаитам, кочевали не только в долине Дона, но и на всей территории междуречья Волги-Дона, то есть там, где со второй половины II в. н.э. распространились памятники позднесарматской культуры. Главной задачей кочевников, учитывая внешнеполитические интересы Римской империи в данном регионе, по-видимому, являлось перекрытие аланам, которых Антонин Пий «не раз обуздывал ... когда они приходили в движение» (SHA. Pii. III. 5, 5), всех путей, ведущих в степи Северного Причерноморья. Именно благодаря этому обстоятельству танаиты, будучи связанными родственными узами как с боспорскими царями, так и с сарматскими кланами (через Фарзоя, Инисмея и их потомков?), стали играть роль своеобразного моста между Боспором и сарматским миром $^{38}$. Отсюда происходит особая значимость и даже возможно государственный характер заключенных здесь договоров, что определенно просматривается, в так называемых, «энциклопедиях тамг» ${ }^{39}$. Видимо не случайно на этих каменных плитах со скоплением сарматских знаков I-III вв. н.э. широко представлены и знаки боспорских царей и цариц начиная с Аспурга до Ининфимея ${ }^{40}$. Вот почему появление общины танаитов, вряд ли, имело какое-нибудь отношение к естественному процессу седентаризации - оседанию кочевников на землю, как считают некоторые ученые ${ }^{41}$.

${ }^{37}$ Толочко И.В. Некрополь Танаиса I-III вв. н.э. // Боспорские чтения. Керчь, 2003. Вып. IV. С. 257-258; Безуглов С.И. Ук. соч. С. 109; Вдовиченков E.B. Кем были танаиты (к вопросу об этнической принадлежности нового населения Танаиса II-III вв. н.э.) // Вестник Танаиса. X Недвиговка Мясниковского района Ростовской области, 2012. С. 166-167; Вдовченков E.B. Сарматы в Танаисе ... С. 81-85.

${ }^{38}$ Вдовиченков Е.В. Кем были танаиты ... С. 167.

39 Яценко С.А. Знаки-тамги ... С. 80-81.

40 При этом не исключено, что некоторые тамги боспорских царей, на указанные плиты со скоплением сарматских знаков, добавлялись позже (Яценко С.А., Раев Б.А. Плиты со скоплениями сарматских знаков из Танаиса в собрании Новочеркасского музея // Боспорский феномен. СПб., 2001. Ч.ІІ. С. 227-228).

${ }^{41}$ Вдовиченков Е.В. Кем были танаиты ... С. 168-169.
Известно, что в начавшихся в правлении Марка Аврелия (161-180 гг.) Маркоманских войнах (167180 гг.) активное участие принимали многочисленные племена, в том числе и сарматы, в которых справедливо видят языгов Тисской равнины ${ }^{42}$. Однако участие аланов во всех этих событиях сомнительно. Судя по молчанию такого авторитетного и осведомленного историка, как Дион Кассий, аланов эта война явно обошла стороной ${ }^{43}$. Они упоминаются лишь в общем списке варваров, устроивших заговор против империи в самом начале Маркоманских войн (SHA. Capit. Marc. 22, 1-2). Однако этот довольно беспорядочный перечень племен «сочинителей истории Августов» не внушает доверия и справедливо считается недостоверным ${ }^{44}$. Существует, правда, еще и мнение Беккера, исправившего в «Римской истории» Диона Кассия некое испорченное слово на «алан», по причине чего появилась возможность допустить, что аланы, заключая мир в начале правления Коммода (180-192 гг.), передали римлянам пятнадцать тысяч захваченных пленных и обещали «не пасти свои стада на своих землях ближе сорока стадиев от пределов Дакии» (Dio Cass. LXXIII. 3, 1-3). Эта сомнительная конъюнктура также не может быть принята наукой ${ }^{45}$.

Археологические источники не противоречат нашему предположению о перекрытии сарматами аланам путей в Северное Причерноморье. Несмотря на то что в самом начале формирования позднесарматской культуры в ее ареал входили территории от Южного Приуралья до Подунавья, во второй половине II в. н.э. на территории Северного Причерноморья происходит значительное сокращение сарматского населения, за исключением северо-западных областей между Днестром и Дунаем. Основная масса кочевников, как и ранее, сосредотачивается в волго-донских степях ${ }^{46}$. При этом наиболее

42 Дзиговский А.Н. Очерки истории сарматов Карпато-Днепровских земель. Одесса, 2003. С. 153-154.

${ }^{43}$ Дзиговский А.Н. Очерки ... С. 154.

${ }^{44}$ Алемань А. Аланы в древних и средневековых письменных источниках. М., 2003. С. 53.

${ }^{45}$ Алемань А. Ук. соч. С. 132-133.

${ }^{46}$ Дзиговский А.Н. Сарматские памятники степей Северо-Западного Причерноморья // Археологические памятники Северо-ЗападногоПричерноморья.Киев, 1982.С. 84;МошковаМ.Г. Позднесарматская культура ... С. 191. Судя по письменным и археологическим источникам, во времена Адриана и Мар- 


\section{Политика и общество 5 (113) • 2014}

яркая черта раннеаланской культуры - Т-образные катакомбы не получают распространение на указанной территории ${ }^{47}$. Этот факт вызывает интерес в связи с тем, что у степного населения предыдущего среднесарматского времени не существовало проблем во взаимоотношениях с мигрантами. Считается, что жившие здесь «средние» сарматы принимали участие в формировании в центральных районах Северного Кавказа аланской культуры, окончательно сложившейся ко второй половине II в. н.э. Однако памятники позднесарматской культуры в степной и предгорной полосе Северного Кавказа практически неизвестны, а влияние носителей позднесарматской культуры на погребальный обряд населения Северного Кавказа не прослеживается $^{48}$. Это свидетельствует об отсутствии контактов и даже, возможно, враждебных отношениях между «поздними» сарматами и аланами. К приведенным аргументам можно добавить и данные ольвийской эпиграфики (IOSPE. I 251,54$)$, которые свидетельствуют о мирных отношениях Ольвии со своим варварским окружением во второй половине II в. н.э. ${ }^{49}$

Итак, очевидно, что начавшийся кризис, вызванный миграцией в Северное Причерноморье в середине II в. н.э. нового массива кочевых племен, заставил римлян изменить свою стратегию в данном регионе. Империи пришлось восстановить контакты с могущественными сарматскими кланами, которые помогли утвердить римскую гегемонию в Северном Причерноморье и вернуть в регион утраченный мир. При этом функцию первого пояса

ка Аврелия, на землях к западу от Днепра господствовали роксоланы (Дзиговский А.Н. Очерки ... С. 150-153).

47 В Калмыкии, Заволжье и Южном Приуралье Т-образных катакомб нет вообще, а в южной части междуречья Волги-Дона и на правобережье Нижнего Дона, они появились только во второй половине III в. н.э. (Мошкова М.Г. Анализ сарматских погребальных памятников II-IV вв. н.э. // Статистическая обработка погребальных памятников Азиатской Сарматии. Вып. IV: Позднесарматская культура. М., 2009. C. 92).

48 Маламев В.Ю. Курганные могильники равнинной части центральных и восточных районов Северного Кавказа I-IV вв. н.э. // Погребальный обряд ранних кочевников Евразии. Материалы и исследования по археологии Юга России. Ростов-на-Дону, 2011. Вып. III. С. 254-260.

${ }^{49}$ Антонова И.А., Яйленко В.П. Херсонес, Северное Причерноморье и Маркоманнские войны по данным херсенесского декрета 174 г. н.э. в честь Тита Аврелия Кальпурния Аполлонида // ВДИ. 1995. №4. С. 78. обороны взяли на себя союзные сарматские орды, кочевавшие в междуречье Дона-Волги и не пропускавшие враждебных варваров из аланского племенного союза в причерноморские степи. Именно для координации военных действий с сарматскими союзниками, в том числе и с целью воздействия на них через культурную экспансию, отдельные представители варварской знати и были организованы в равноправную с эллинами общину и расселены в Танаисе.

\section{Библиография:}

1. Алемань А. Аланы в древних и средневековых письменных источниках. М., 2003.

2. Антонова И.А., Яйленко В.П. Херсонес, Северное Причерноморье и Маркоманнские войны по данным херсенесского декрета 174 г. н.э. в честь Тита Аврелия Кальпурния Аполлонида // ВДИ. 1995. №4. С. 58-86.

3. Арсеньева Т.М., Науменко С.А. Раскопки Танаиса в 1981-1984 гг. // КСИА. 1989. №191. C. $75-82$.

4. Арсеньева Т.М., Науменко С.А. Комплекс находок из подвала МБ ІІ-ІІІ вв. н.э. // Вестник Танаиса. Ростов-на-Дону, 1994. Вып.1. С. 61-113.

5. Батиева Е.Ф. Население Нижнего Дона в IX в. до н.э. - IV в. н.э. (палеоантропологическое исследование). Ростов-на-Дону, 2011.

6. Безуглов С.И. Позднесарматская культура и Нижний Дон (современное состояние проблемы) // Становление и развитие позднесарматской культуры (по археологическим и естественнонаучным данным). Волгоград, 2010. С. 93-116.

7. Вдовиченков Е.В. Кем были танаиты (к вопросу об этнической принадлежности нового населения Танаиса II-III вв. н.э.) // Вестник Танаиса. X Недвиговка Мясниковского района Ростовской области, 2012. С. 163-171.

8. Вдовченков Е.В. Сарматизация Танаиса как частный случай взаимодействия цивилизации и варварства // Цивилизация и варварство: трансформация понятий и региональный опыт. М., 2012. С. 197-219.

9. Вдовченков Е.В. Сарматы в Танаисе: культурные последствия седентаризации // Боспорские чтения. Керчь, 2013. Вып. XIV. C. 81-85. 
10. Внуков С.Ю. Время и политические последствия появления племен позднесарматской культуры в Причерноморье // ВДИ. 2007. №4. С. 163-177.

11. Гайдукевич В.Ф. Боспорское царство. М; Л., 1949.

12. Горончаровский В.А. Военно-политическая история Боспорского царства во второй половине I - середине III вв. н.э.: от прочного союза с Римом до Готских войн // МНЕМОН. Исследования и публикации по истории античного мира. СПб., 2005. Вып.4. С. 337-358.

13. Даньшин Д.И. Танаиты и танаисцы во II-III вв. н.э. // КСИА. №197. С.51-56.

14. Дашевская О.Д. Граффити на стенах здания в Неаполе Скифском // СА. 1962. №1. С. 259-261.

15. Дзиговский А.Н. Сарматские памятники степей Северо-Западного Причерноморья // Археологические памятники Северо-Западного Причерноморья. Киев, 1982. С. 83-92.

16. Дзиговский А.Н. Очерки истории сарматов Карпато-Днепровских земель. Одесса, 2003.

17. Завойкина Н.В. Т $\alpha v \alpha \varepsilon \check{т} \alpha \iota$ в истории Боспорского царства // Древности Боспора. М., 2004. С. 163-197.

18. Завойкина Н.В. Боспорские фиасы: между полисом и монархией. М., 2013.

19. Зайцев Ю.П. Золотой статер Риметалка из Неаполя Скифского // СА. 1990. №1. С. 259-261.

20. Иванчик А.И. Три надписи фиасов эллинистического времени из Танаиса (новые данные о греко-иранском взаимодействии в Танаисе дополемоновской эпохи) // ВДИ. 2008. №2. С. 57-67.

21. Малашев В.Ю. Курганные могильники равнинной части центральных и восточных районов Северного Кавказа I-IV вв. н.э. // Погребальный обряд ранних кочевников Евразии. Материалы и исследования по археологии Юга России. Ростов-на-Дону, 2011. Вып. III. С. 254-260.

22. Молчанов А.А. Высшие магистраты Танаиса IIIII вв. и происхождение дуалистической системы его устройства // Проблемы истории СССР. M., 1976. С. 71-85.

23. Мошкова М.Г. Позднесарматская культура // Степи европейской части СССР в скифо-сарматское время (Археология СССР с древнейших времен до средневековья в 20 томах). М., 1989. С. 191-201.
24. Мошкова М.Г. Предисловие // Статистическая обработка погребальных памятников Азиатской Сарматии. Вып. IV: Позднесарматская культура. М., 2009. С. 6-8.

25. Мошкова М.Г. Анализ сарматских погребальных памятников II-IV вв. н.э. // Статистическая обработка погребальных памятников Азиатской Сарматии. Вып. IV: Позднесарматская культура. М., 2009. С. 21-162.

26. Науменко С.А. Комплекс находок из подвала МБ ІІ-ІІІ вв. н.э. // Вестник Танаиса. Ростов-наДону, 1994. Вып.1. С. 61-113.

27. Перевалов С.М. Римская стратегия на Кавказе в Каппадокийское легатство Флавия Арриана // Перевалов С.М. Тактические трактаты Флавия Арриана: Тактическое искусство; Диспозиция против аланов (Сер. Древнейшие источники по истории Восточной Европы). М., 2010. С. 303-377.

28. Пуздровский А.Е. Политическая история Крымской Скифии (II в. до н.э. - III в.н.э.) // ВДИ. 2001. №3. С. 86-118.

29. Сапрыкин С.Ю. К вопросу о сарматизации Боспора рубежа нашей эры // Северное Причерноморье в эпоху античности и средневековья. Труды ГИМ. М., 2006. Вып. 159. С. 236-244.

30. Соломоник Э.И. Сарматские знаки Северного Причерноморья. Киев, 1959.

31. Толочко И.В. Некрополь Танаиса I-ІІІ вВ. н.э. // Боспорские чтения. Керчь, 2003. Вып. IV. С. 248-258.

32. Фролова Н.А. Из истории Боспора в середине ІІ в. н.э. // ВДИ. 1972. №1. С. 187-193.

33. Храпунов И.Н. Этническая история Крыма в раннем железном веке // Боспорские исследования. Симферополь; Керчь, 2004. Вып.VI.

34. Цветаева Г.А. Боспор и Рим. М., 1979.

35. Шаров О.В. Боспор и варварский мир Центральной и Восточной Европы в позднеримскую эпоху (середина II - середина IV вв. н.э.). Автореф. дис. ... док. ист. наук. СПб., 2009.

36. Шелов Д.Б. Тамга Риметалка // Культура античного мира. М., 1966. С. 268-277.

37. Шелов Д.Б. Танаис и Нижний Дон в III-I вв. М., 1970.

38. Шелов Д.Б. Танаис и Нижний Дон в первых веках нашей эры. М., 1972.

39. Шелов Д.Б. Некоторые вопросы этнической истории Приазовья II-III вв. н.э. по данным танаисской ономастики // ВДИ. 1974. №1. С. 80-93. 


\section{Политика и общество 5 (113) • 2014}

40. Яйленко В.П. Гунно-болгары II-V вв. н.э. на Боспоре по данным эпиграфики и антропонимики // Древности Боспора. М., 2002. Вып. 5. С. 317-320.

41. Яйленко В.П. Тысячелетний боспорский рейх. История и эпиграфика Боспора VI в. до н.э. V в. н.э. М., 2010.

42. Ярцев С.В. Проблема этнической идентификации варваров, напавших на Ольвию во время правления Антонина Пия // ВДИ. 2011. №2. С. 144-164.

43. Яценко С.А. Аланы в Восточной Европе в середине I - середине IV вв. н.э. // ПАВ. 1993. №6. C.83-88.

44. Яценко С.А. Знаки-тамги ираноязычных народов древности и раннего средневековья. М., 2001.

45. Яценко С.А. Алания I-II вв. н.э. как кочевая империя // Монгольская империя и кочевой мир. Улан-Удэ, 2009. Вып. 3. С. 281-310.

46. Яценко С.А. К дискуссии об оформлении позднесарматской этнокультурной общности 2-й пол. II - 1-й пол. III вв. н.э. // Нижневолжский археологический вестник. Волгоград, 2011. Вып. 12. С. 197-213.

47. Яценко С.А., Раев Б.А. Плиты со скоплениями сарматских знаков из Танаиса в собрании Новочеркасского музея // Боспорский феномен. СПб., 2001. Ч.ІІ. С. 222-230.

\section{References (transliteration):}

1. Aleman' A. Alany v drevnikh i srednevekovykh pis'mennykh istochnikakh. M., 2003.

2. Antonova I.A., Yailenko V.P. Khersones, Severnoe Prichernomor'e i Markomannskie voiny po dannym khersenesskogo dekreta 174 g. n.e. V chest' Tita Avreliya Kal'purniya Apollonida // VDI. 1995. №4. S. 58-86.

3. Arsen'eva T.M., Naumenko S.A. Raskopki Tanaisa v 1981-1984 gg. // KSIA. 1989. №191. S. 75-82.

4. Arsen'eva T.M., Naumenko S.A. Kompleks nakhodok iz podvala MB II-III vv. n.e. // Vestnik Tanaisa. Rostov-na-Donu, 1994. Vyp.1. S. 61-113.

5. Batieva E.F. Naselenie Nizhnego Dona v IX v. do n.e. - IV v. n.e. (paleoantropologicheskoe issledovanie). Rostov-na-Donu, 2011.

6. Bezuglov S.I. Pozdnesarmatskaya kul'tura i Nizhnii Don (sovremennoe sostoyanie problemy) //
Stanovlenie i razvitie pozdnesarmatskoi kul'tury (po arkheologicheskim i estestvennonauchnym dannym). Volgograd, 2010. S. 93-116.

7. Vdovichenkov E.V. Kem byli tanaity (k voprosu ob etnicheskoi prinadlezhnosti novogo naseleniya Tanaisa II-III vv. n.e.) // Vestnik Tanaisa. X Nedvigovka Myasnikovskogo raiona Rostovskoi oblasti, 2012. S. 163-171.

8. Vdovchenkov E.V. Sarmatizatsiya Tanaisa kak chastnyi sluchai vzaimodeistviya tsivilizatsii i varvarstva // Tsivilizatsiya i varvarstvo: transformatsiya ponyatii i regional'nyi opyt. M., 2012. S. 197-219.

9. Vdovchenkov E.V. Sarmaty v Tanaise: kul'turnye posledstviya sedentarizatsii // Bosporskie chteniya. Kerch', 2013. Vyp. XIV. S. 81-85.

10. Vnukov S.Yu. Vremya i politicheskie posledstviya poyavleniya plemen pozdnesarmatskoi kul'tury v Prichernomor'e // VDI. 2007. №4. S. 163-177.

11. Gaidukevich V.F. Bosporskoe tsarstvo. M; L., 1949.

12. Goroncharovskii V.A. Voenno-politicheskaya istoriya Bosporskogo tsarstva vo vtoroi polovine I seredine III vv. n.e.: ot prochnogo soyuza s Rimom do Gotskikh voin // MNEMON. Issledovaniya i publikatsii po istorii antichnogo mira. SPb., 2005. Vyp.4. S. 337-358.

13. Dan'shin D.I. Tanaity i tanaistsy vo II-III vv. n.e. // KSIA. №197. S.51-56.

14. Dashevskaya O.D. Graffiti na stenakh zdaniya v Neapole Skifskom // SA. 1962. №1. S. 259-261.

15. Dzigovskii A.N. Sarmatskie pamyatniki stepei Severo-Zapadnogo Prichernomor'ya // Arkheologicheskie pamyatniki Severo-Zapadnogo Prichernomor'ya. Kiev, 1982. S. 83-92.

16. Dzigovskii A.N. Ocherki istorii sarmatov KarpatoDneprovskikh zemel'. Odessa, 2003.

17. Zavoikina N.V. Tavacital v istorii Bosporskogo tsarstva // Drevnosti Bospora. M., 2004. S. 163-197.

18. Zavoikina N.V. Bosporskie fiasy: mezhdu polisom i monarkhiei. M., 2013.

19. Zaitsev Yu.P. Zolotoi stater Rimetalka iz Neapolya Skifskogo // SA. 1990. №1. S. 259-261.

20. Ivanchik A.I. Tri nadpisi fiasov ellinisticheskogo vremeni iz Tanaisa (novye dannye o greko-iranskom vzaimodeistvii v Tanaise dopolemonovskoi epokhi) // VDI. 2008. №2. S. 57-67.

21. Malashev V.Yu. Kurgannye mogil'niki ravninnoi chasti tsentral'nykh i vostochnykh raionov Sever- 
nogo Kavkaza I-IV vv. n.e. // Pogrebal'nyi obryad rannikh kochevnikov Evrazii. Materialy $\mathrm{i}$ issledovaniya po arkheologii Yuga Rossii. Rostovna-Donu, 2011. Vyp. III. S. 254-260.

22. Molchanov A.A. Vysshie magistraty Tanaisa IIIII vv. i proiskhozhdenie dualisticheskoi sistemy ego ustroistva // Problemy istorii SSSR. M., 1976. S. 71-85.

23. Moshkova M.G. Pozdnesarmatskaya kul'tura // Stepi evropeiskoi chasti SSSR v skifo-sarmatskoe vremya (Arkheologiya SSSR s drevneishikh vremen do srednevekov'ya v 20 tomakh). M., 1989. S. 191-201.

24. Moshkova M.G. Predislovie // Statisticheskaya obrabotka pogrebal'nykh pamyatnikov Aziatskoi Sarmatii. Vyp. IV: Pozdnesarmatskaya kul'tura. M., 2009. S. 6-8.

25. Moshkova M.G. Analiz sarmatskikh pogrebal'nykh pamyatnikov II-IV vv. n.e. // Statisticheskaya obrabotka pogrebal'nykh pamyatnikov Aziatskoi Sarmatii. Vyp. IV: Pozdnesarmatskaya kul'tura. M., 2009. S. 21-162.

26. Naumenko S.A. Kompleks nakhodok iz podvala MB II-III vv. n.e. // Vestnik Tanaisa. Rostov-naDonu, 1994. Vyp.1. S. 61-113.

27. Perevalov S.M. Rimskaya strategiya na Kavkaze v Kappadokiiskoe legatstvo Flaviya Arriana // Perevalov S.M. Takticheskie traktaty Flaviya Arriana: Takticheskoe iskusstvo; Dispozitsiya protiv alanov (Ser. Drevneishie istochniki po istorii Vostochnoi Evropy). M., 2010. S. 303-377.

28. Puzdrovskii A.E. Politicheskaya istoriya Krymskoi Skifii (II v. do n.e. - III v.n.e.) // VDI. 2001. №3. S. 86-118.

29. Saprykin S.Yu. K voprosu o sarmatizatsii Bospora rubezha nashei ery // Severnoe Prichernomor'e v epokhu antichnosti i srednevekov'ya. Trudy GIM. M., 2006. Vyp. 159. S. 236-244.

30. Solomonik E.I. Sarmatskie znaki Severnogo Prichernomor'ya. Kiev, 1959.

31. Tolochko I.V. Nekropol' Tanaisa I-III vv. n.e. // Bosporskie chteniya. Kerch', 2003. Vyp. IV. S. 248-258.

32. Frolova N.A. Iz istorii Bospora v seredine II v. n.e. // VDI. 1972. №1. S. 187-193.
33. Khrapunov I.N. Etnicheskaya istoriya Kryma v rannem zheleznom veke // Bosporskie issledovaniya. Simferopol'; Kerch', 2004. Vyp.VI.

34. Tsvetaeva G.A. Bospor i Rim. M., 1979.

35. Sharov O.V. Bospor i varvarskii mir Tsentral'noi i Vostochnoi Evropy v pozdnerimskuyu epokhu (seredina II - seredina IV vv. n.e.). Avtoref. dis. ... dok. ist. nauk. SPb., 2009.

36. Shelov D.B. Tamga Rimetalka // Kul'tura antichnogo mira. M., 1966. S. 268-277.

37. Shelov D.B. Tanais i Nizhnii Don v III-I vv. M., 1970.

38. Shelov D.B. Tanais i Nizhnii Don v pervykh vekakh nashei ery. M., 1972.

39. Shelov D.B. Nekotorye voprosy etnicheskoi istorii Priazov'ya II-III vv. n.e. po dannym tanaisskoi onomastiki // VDI. 1974. №1. S. 80-93.

40. Yailenko V.P. Gunno-bolgary II-V vv. n.e. na Bospore po dannym epigrafiki i antroponimiki // Drevnosti Bospora. M., 2002. Vyp. 5. S. 317-320.

41. Yailenko V.P. Tysyacheletnii bosporskii reikh. Istoriya i epigrafika Bospora VI v. do n.e. - V v. n.e. M., 2010.

42. Yartsev S.V. Problema etnicheskoi identifikatsii varvarov, napavshikh na Ol'viyu vo vremya pravleniya Antonina Piya // VDI. 2011. №2. S. 144164.

43. Yatsenko S.A. Alany v Vostochnoi Evrope v seredine I - seredine IV vv. n.e. // PAV. 1993. №6. S.83-88.

44. Yatsenko S.A. Znaki-tamgi iranoyazychnykh narodov drevnosti i rannego srednevekov'ya. M., 2001.

45. Yatsenko S.A. Alaniya I-II vv. n.e. kak kochevaya imperiya // Mongol'skaya imperiya i kochevoi mir. Ulan-Ude, 2009. Vyp. 3. S. 281-310.

46. Yatsenko S.A. K diskussii ob oformlenii pozdnesarmatskoi etnokul'turnoi obshchnosti 2-i pol. II - 1-i pol. III vv. n.e. // Nizhnevolzhskii arkheologicheskii vestnik. Volgograd, 2011. Vyp. 12. S. 197-213.

47. Yatsenko S.A., Raev B.A. Plity so skopleniyami sarmatskikh znakov iz Tanaisa v sobranii Novocherkasskogo muzeya // Bosporskii fenomen. SPb., 2001. Ch.II. S. 222-230. 